\title{
DO COMPASSIONATE FIRMS OUTPERFORM? THE ROLE OF ORGANIZATIONAL LEARNING
}

\section{INTRODUCTION}

Workplaces can be hostile environments in which employees often experience pain and suffering, which is pervasive and can dramatically impact the work environment and be highly costly (Dutton et al., 2014; Lilius et al., 2008). Recognizing the negative consequences of suffering in organizations, workplace compassion has been recently proposed as essential way to alleviate this suffering in organizational settings, which in turn may improve collective capabilities such organizational resilience, innovation, learning and performance (Worline and Dutton, 2017). Workplace compassion is defined as an interpersonal process involving the noticing, feeling, sense making, and acting in a way that alleviates the suffering of another person (Dutton et al., 2014).

In an increasingly interconnected, painful and unequal world, compassion is considered as timely and timeless since it is essential for human interrelating and responding to suffering (Kanov et al., 2004). Yet, since the system of capitalism and the pillar of self-interest have dominated the business arena (George, 2014; Melé, 2012), companies have usually moved away from encouraging love, caring and compassion in the workplace. Hence, values such as domination, aggression, ambition, competition continue to prevail in organizations.

Nevertheless, new scientific evidence about human motivation and behavior suggests that compassion is a normal and pervasive way of interrelating at work (and beyond) (Dutton et al., 2014). In accordance, a paradigm shift in management rooted on care and compassion has been recently proposed, in contrast to self-interest theories (Rynes et al., 2012). This alternative approach seeks moving away from theories based on self-interest motivation and predominance of rationale over emotions in which management research typically has been focused. In line with this new paradigm, academics have noted that suffering is a fact of life, which requires a response by management research and practice since organizations may be sites of pain and suffering but also places of healing, when caring and compassion are displayed (Kanov et al., 2004; Frost et al., 2000).

Following this alternative paradigm, in the last few years an emergent body of research has theoretically supported that workplace compassion yields collective benefits like shared positive emotions, greater collective commitment, lower turnover rates, customer retention and even better financial performance (Cameronet al., 2011; Dutton et al. 2006; Lilius et al. 2008). Moreover, 
compassion has been also proposed as a collective capacity that cannot be easily substituted or imitated and therefore be particularly advantageous over the long term (Kanov et al., 2004; Lilius et al., 2011). In fact, an incipient body of organizational literature has advocated for the workplace compassion and the examination of its consequences in organizations (e.g., Atkins and Parker, 2012; Dutton et al., 2007; Frost et al., 2006; Lilius et al., 2008). However, although most of the literature on compassion seems to agree that it has important benefits for organizations, at least theoretically, implying that it promotes organizational performance (Lilius et al., 2011), this topic has been largely neglected in management field and only recently has begun to receive more attention by organizational researchers. Moreover, although some quantitative studies have been conducted (i.e., Cameron et al., 2004; Lillius et al., 2008), most research on workplace compassion has consisted mainly of theoretical studies. Consequently, academics called for more extensive empirical research on the organizational consequences of compassion as a collective capability (Dutton et al., 2014; George, 2014).

Accordingly, in this article we aim to empirically examine the outcomes of compassion. More specifically, we aim to test the direct effects of organizational compassion on firm performance and indirect effects affecting such relationship as well. As compassion has been suggested to encourage human-based collective capabilities such as learning, which contribute to sustainable competitive advantage (Worline and Dutton, 2017), we propose that organizational learning may mediate in the relationship between compassion and firm performance. Hence, by revealing some of the consequences of compassion at work we want to take a step forward in the validation of the new management theories and practices based on a compassionate approach. Moreover, since management research has often failed to see organizations as human institutions with members who suffer, care and respond to pain (George, 2014; Rynes et al., 2012), examining the role of compassion in organizational life may offer a more human and precise view of organizations, helping to fill a gap in the field of organizational literature. To examine these relationships we have carried out two empirical analysis on different samples.

After this introduction, we make a brief review of the concept of workplace compassion. Then we review the theory of relations between the constructs of this research and propose the hypotheses of the study. We then explain the methodology used in this research. Finally, we provide the results of both empirical analysis and draw conclusions, profiling the implications and limitations of our study and suggestions for future research. 


\section{THEORETICAL FRAMEWORK: COMPASSION AT WORK}

The study on compassion is not something new. Disciplines such as religion, philosophy, sociology have been studying this phenomenon for more than 2,000 years. However, this concept has only recently been introduced in the field of management. In fact, it was not considered a topic worthy of being explored in organizations until 1999 when Peter Frost claimed for the importance of workplace compassion. From that moment, interest arose in this phenomenon, which was reinforced when the author advised that the inevitable pain generated within organizations needs an academic response (Frost, 2003).

Once interest has been aroused, several researchers have focused their efforts on the study of compassion. Specifically, Kanov et al. (2004) synthesized a long historical tradition in philosophy and theology, building on Clark (1997), who proposed a tripartite model of the compassion process that incorporated cognitive, affective, and behavioral components. From this model, emerged the definition of compassion as noticing, feeling, and acting to alleviate the suffering of others (Kanov et al., 2004). Currently, this first definition has incorporated a fourth process that consists of making meaning of suffering in a way that contributes to a desire to alleviate it. Therefore, compassion is a four-part process that involves: (1) noticing that suffering is present in an organization, (2) making meaning of suffering in a way that contributes to a desire to alleviate it, (3) feeling empathic concern for the people suffering, and (4) taking action to alleviate suffering in some manner (Worline and Dutton, 2017). Therefore, compassion could be defined as an interpersonal process involving the noticing, feeling, sensemaking and acting that alleviates the suffering of another person (Dutton et al., 2014).

Specifically, in the context of this research, compassion is addressed at an organizational level. Therefore, according to the above conceptualization of compassion, in this study organizational compassion is considered as the level in which organizational members notice, feels, sense makes and acts to alleviate others' suffering. In this sense, organizational compassion is a social process in which employees collectively acknowledge that pain is present, share and express their empathy, and respond to suffering in a collective way (Lilius et al., 2011). This shared acknowledgement that suffering is present often leads to coordinated action to address or alleviate pain (Lilius et al., 2011). According to Dutton et al. (2014, p. 283), "acting compassionately can involve a breadth of different behaviors, ranging from mere presence or listening to more elaborated, coordinated, and durable actions that involve directing multiple resources toward a sufferer". These recourses include for example giving clothing, food or cards or other intangible such attention, time, concern, creation of safe psychological space (Frost et al., 2006). Moreover, compassionate actions also involve withholding or delaying actions when doing so is believed to be most helpful to the sufferer (Dutton $e t$ al., 2014). 
Organizations enable organizational compassion by facilitating some processes that contribute to the creation of resources, the strengthening of certain shared beliefs and values, and the cultivation of key relational skills, which triggers the noticing, feeling, and responding to pain of their members (Dutton et al., 2005). For example, organizational structure and formal programs can be designed to enhance organizational compassion (Lilius et al., 2011). More specifically, organizations can designate specific roles to detection of and response to human suffering (i.e., ombudspersons, grief counsellors, and patient advocates). Moreover, some organizational programs can also deliver compassion. For example, organizations may create a fund where employees can choose to regularly contribute that provides financial support for other employees are going through economic emergency or facilitating that employees can donate vacation time to other employees who are facing a family emergency.

According to Frost et al. (2006), compassion is a healing force that is essential to flourish in organizations since it enhances the human capabilities that are necessary for an organization to succeed. For example, compassion is theoretically supposed to enhance employee attachment and commitment to their organization (Grant et al., 2008; Lilius et al., 2008) or allow the sharing of positive emotions such as pride and gratefulness (Dutton et al., 2006). Moreover, Dutton et al. (2014) consider that compassion has effects on all members of an organization, affecting the entire organization. On one side, compassion positively affects the person who exercises it due to the satisfaction that comes from helping others (Stamm, 2002), since compassion is associated with seeing oneself as a caring person (i.e. prosocial identity) (Grant et al., 2008). On the other side, compassion also benefits sufferers since the person shapes their sensemaking about oneself seeing the self as more capable, peers as more humane and organization as caring. Furthermore, compassion also improves the relationship between the person who exercises it and the person who perceives it. Because compassion breeds trust, among other factors, as suggested by Clark (1997) and Dutton et al. (2007), connections between co-workers become stronger (Frost et al., 2000; Powley, 2009).

Likewise, compassion affects not only the direct subjects, those who participate in the compassionate acts, but also the witnesses of those acts. These third persons feel pride in how the members of their organization act (Dutton et al., 2007) and can be more predisposed to act toward the common good (Haidt, 2003).

Although organizations are sites of pain and suffering, they can also be places of healing, where compassion is both given and received (Kanov et al., 2004). That is why is essential to give value to everything that can help alleviate this suffering. In this sense, compassion within organizations turns out to be a very powerful tool of healing and strength. As Dalai Lama (1995) said, where there is suffering, there is also the human capacity for compassion. 


\section{HYPOTHESES DEVELOPMENT}

\section{Compassion and firm performance}

While research on compassion at work is still relatively limited, there is growing evidence of its importance for organizations. For example, literature has suggested that compassion could improve some aspects that lead to greater performance, such as trust (Simosko, 2015), affective commitment (Madden et al., 2012), customer satisfaction (Backhaus and Tikoo, 2004), positive emotions (Madden et al., 2012), employee engagement, higher quality peer relationships, prosocial behaviors (Batson, 1991; Dutton et al., 2006), or employee attraction (Frost et al., 2000) and retention (Lilius et. al., 2011; Madden et al., 2012). Indeed, work units high in compassion experience lower rates of employee turnover and attract more new members than do work units that are lower in compassion (Frost et al., 2000; Lilius et al., 2011). In this way, compassion in organizations leads to a reduction in the costs of absenteeism and in staff rotation (Dutton et al., 2006).

Moreover, Worline and Dutton (2017) suggest that organizational compassion can support several types of strategic advantage that affect firm performance such as innovation, service quality, collaboration, retaining talented people, employee and customer engagement, and adaptability to change. In addition, capabilities that are difficult to imitate or replace-such as acting with compassion - are particularly advantageous in the long term (Barney, 1995). Compassion is associated with a set of positive attitudes, emotions, and feelings in organizations, and so it can contribute to firm performance by helping individuals who receive it to resume or rejoin their work after an episode of suffering (Lilius et al., 2011). In contrast, a climate of suffering within organizations has serious implications for organizational performance and productivity (Kanov et al., 2004). It has been estimated that grief costs business several billions of dollars a year, in terms of decreased individual productivity (Zaslow, 2002).

Therefore, compassion may be a source of competitive advantage which may lead to increased levels of firm performance. Although the idea that compassion might improve firm performance has been theorized (i.e., Lilius et al., 2011), little empirical evidence has been found to support it. Thus, although several studies reveal a range of valuable individual and organizational outcomes associated with compassion that affect firm performance, it is a research breakthrough to empirically examine the links between compassion and firm performance. Accordingly, we propose the following hypothesis:

H1: Compassion at work is positively related to firm performance 


\section{The mediating role of organizational learning capability between compassion and firm performance}

Evidence indicates that compassion at work brings a range of collective capabilities such creativity, innovation and learning, which fuels strategic advantage (Worline and Dutton, 2017). According to Worline and Dutton (2017, p.20), "compassion helps people to greet errors and failures with the openmindedness and openheartedness that foster learning". Thus, compassion fosters a climate of psychological safety that enables the discussion of ideas, acting on creative ideas, learning from errors or talking more openly and frequently. As a result, people become more innovative and learn more (Worline and Dutton, 2017). Moreover, research suggests that both the recipient and provider might learn from the exchange that occurs when participating in problem-solving interactions to alleviate suffering (i.e., compassion) (Elkjaer, 2003; Feldman and March, 1981). Likewise, since compassion is based on relationships and relatedness (Rynes et al., 2012), it has been suggested to foster the exchange of knowledge that enhances learning (Edmonson, 2012; Lin, 2007; Worline and Dutton, 2017). Accordingly, we propose that workplace compassion may create a work environment that increases organizational learning capability (OLC).

OLC refers to the organizational and managerial characteristics that facilitate the organizational learning process (Dibella et al., 1996; Goh and Richards, 1997). Organizational learning can be understood as the process of social construction of shared beliefs and meanings, in which the social context plays an essential role (Chiva and Alegre, 2005). For this reason, the concept of OLC gives importance to the facilitating factors for organizational learning (Chiva and Alegre, 2008; Chiva et al., 2007). Therefore, for the OLC to be fostered, there must be a work environment that allows it. In this sense, compassion seem to be crucial in building warm and positive environments that may promote certain characteristics which lead to OLC. We propose that a compassionate atmosphere could facilitate the five factors that appear to explain organizational learning capability, i.e. experimentation, risk taking, interaction with the external environment, dialogue and participative decision-making (Chiva et al., 2007).

As we indicated above, compassion creates a trustworthy work environment and psychological safety (Worline and Dutton, 2017) which is essential for the appearance of new ideas. Thus, if the members of the organization do not feel that they can express their ideas without being judged or attacked, they will not share them with the rest of the organization. It is very important that the work environment allows to take risks, since risk-taking is necessary for the generation of new ideas (Amabile et al., 1996), and should therefore be tolerated in order to promote learning. In a compassionate atmosphere, people feel more confident to suggest their own ideas and to think constructively about the ideas of others (Worline and Dutton, 2017). For that reason, compassion gets people to recognize mistakes and failures with an open mind and an open heart that encourage learning (Edmondson, 2012). In sum, the 
call for compassion in people's work will create a compassionate, trusting atmosphere, which will greatly facilitate experimentation, risk taking, interaction with the external environment, dialogue and participatory decision-making, dimensions that make up OLC.

In turn, OLC is considered a vital component for the effectiveness and success of an organization (Camps et al., 2016). Research has indicated that OLC is a key variable to increase firm performance (e.g., Alegre and Chiva, 2013; Camps and Luna-Arocas, 2012; Guinot et al., 2013; Tippins and Sohi, 2003). Indeed, OLC is considered as a medium to enhance organization's productivity and performance (Marshall et al., 2009). Thus, OLC may be combined with other firm capabilities (i.e. organizational compassion) to produce positive effects on firm performance. Thereby, in accordance to the above arguments we propose the following hypothesis:

H2: OLC plays a mediating role between the relationship between compassion and firm performance

\section{RESEARCH METHODOLOGY}

We tested the hypothesized relationships in two studies. Study 1 collected data from a sample of firms from Spain with high innovative capability within different sectors. On the other hand, Study 2 collected data from a sample of hotels in Spain. In tandem, these two studies examine the relationships proposed to provide empirical evidence about direct and indirect effects between compassion and firm performance.

In both studies we used the same measurement scales for the variables examined, thus enabling a consistent comparison between the results of the hypothesized relationships. Particularly, we used the following validated measurement scales (the reliability information of each scale is presented in the analysis sections of each one of the studies):

Compassion at work. We assessed compassion at work by using the scale proposed by Petchsawang and Duchon (2009). These authors measure compassion by four items. We have modified those items from the individual level to the organizational level. The questionnaire includes items such: "Employees in this company are aware of and sympathize with their coworkers" or "Employees try to help their coworkers relieve their suffering". The scale used is a 1- to 7-point Likert type one, with 1 indicating the lowest level of compassion and 7 the highest. While the alpha for these original compassion items is weak (.63), it is acceptable and the scale has been widely adopted in numerous studies, some producing stronger alphas (i.e., Petchsawang and McLean, 2017; Gupta, Kumar and Singh, 2014). 
Organizational learning capability. The construct 'Organizational learning capability' was measured by 14 items comprising five dimensions: experimentation, risk taking, interaction with the external environment, dialog, and participative decision making (Chiva and Alegre 2009). An example of item for each dimension are: "People here receive support and encouragement when presenting new ideas" (experimentation); "People are encouraged to take risks in this organization" (risk taking); "There are systems and procedures for receiving, collating and sharing information from outside the company" (interaction with the external environment); “There is a free and open communication within my work group" (dialogue); "Managers in this organization frequently involve employees in important decisions" (participative decision making). All items were measured on a seven-point Likert scale. Previous studies have provided strong alpha coefficients for this scale of OLC (e.g., Chiva and Alegre, 2009; Alegre and Chiva, 2013), thus confirming the internal consistency of the scale.

Firm performance. This scale uses subjective performance indicators about the average firm performance compared to firm's competitors during the last three years. Subjective performance measures have been widely used in the literature (e.g., Camps and Luna-Arocas, 2009; Guinot et al., 2013; Morabito et al., 2010) confirming its adequation and validity. Measures of performance used include the following indicators: economic profitability, sales profitability and annual sales growth. A 1- to 7-point Likert scale was used, where a 1 gives the participating firm the lowest score in relation to its competence and 7 the highest. The internal consistency of this scale has been supported by earlier studies that found acceptable coefficient alphas (e.g., Tippins and Sohi, 2003; Guinot et al., 2013).

\section{Study 1: Sample and data collection}

The study focuses on a population of 11594 firms from Spain. The population was based on a list of companies provided by Spanish Ministry of Economy and Competitiveness. This list gathers heterogeneous sector small-medium size companies that comprises at least one of these requisites regarding innovation: 1) The organization has received public funding for $R \& D$ in the last three years; 2) The organization has demonstrated its innovative character by means of its own development of innovative products/services; 3) The organization has demonstrated the innovative capacity by any official certification recognized by the Ministry of Economy and Competitiveness.

The questionnaire addressed to human resource managers consisted of 18 items (4 items related to compassion at work and 14 items related to OLC), while the questionnaire addressed to general managers had 4 (related to firm performance). The survey was completed via telephone interviews since this technique is useful when interviewing different people in the same company or when people are hard to reach, as in the case of the managers of major companies in this study. Finally, a total of 243 cases were obtained. The fieldwork was carried out in 2015. 


\section{Study 1: Descriptive statistics, psychometric properties of measurement scales and control variables}

Table 1 presents the descriptive statistics of the indicators considered in the study (i.e., means, standard deviations) and correlation factors. To check the reliability of the scale, as well as Cronbach's alpha coefficient (Cronbach, 1951), we have used two indicators: composite reliability (Fornell and Larcker, 1981) and average variance extracted (Alegre and Chiva, 2008) (see Table 2). All Cronbach's alpha coefficient values and those for composite reliability are above the minimum acceptable value 0.7 (Nunnally, 1978). Indeed, the average variance extracted shows values greater than the recommended minimum of 0.5 (Hair et al. 1998; Nunnally, 1978). Finally, the pattern of correlations indicates that compassion and OLC interrelate positively and significantly. To note, the correlation between compassion and firm performance is not significant.

Insert Table 1 Here

Insert Table 2 Here

Given our use of subjective evaluation measures, we conducted a Harman's single-factor test (Podsakoff et al., 2003; Podsakoff and Organ, 1986) to assess whether common method variance exists and to deal with the potential social desirability of the responses. The results of the confirmatory factor analysis with the 22 indicators loading onto a single factor $(\chi 2(209)=2,114.233$; $\mathrm{CFI}=0.493 ; \mathrm{RMSEA}=0.195 ; \mathrm{BBNNFI}=0.440$ ) showed a poor fit, suggesting that the single factor does not account for all of the variance in the data. Consequently, and in accordance with this procedure, we do not consider common method variance to be a problem in our research. 
Control variables. Since firm age and firm size can have an effect on firm performance (e.g., Guinot et al., 2013; Jiménez-Jiménez and Sanz-Valle, 2011), we include these variables as control variables to take account of the external sources that can alter firm performance.

\section{Study 1: Results}

Structural equation modelling (SEM) was used to analyze the theoretical model, using the statistical program EQS 6.1 for Windows. The results confirm an adequate fit of the model with the data used (Chi-Square $=341.624$; degrees of freedom $=244 ;$ Bentler-Bonet Non-Normed Fit $=0.987$; Comparative Fit Index: 0.989; root mean square error of approximation $=0.025)($ see Table 7).

Results for the regression coefficients of the model indicate a positive relationship between compassion and OLC $(\beta 2=0.652 ; \mathrm{t}=8.418 ; \mathrm{p}<0.01)$ and between OLC and firm performance $(\beta 3=0.269 ; \mathrm{t}=2.263 ; \mathrm{p}<0.01)$. However, a non-significant effect was found between compassion and firm performance $(\beta 1=-0.086 ; \mathrm{t}=-0.761 ; \mathrm{p}>0.05)$, thus $\mathrm{H} 1$ was not confirmed.

Results of decomposition effects with standardized values indicate an indirect significant effect between compassion and firm performance with a value of $0.127(\mathrm{t}=2.203)$, thus confirming the existence of a mediation effect through OLC. To confirm whether this mediating effect is partial or total, we compared the mediated model to a constrained model in which the coefficient between compassion and firm performance was equal to zero. This allows us to ascertain whether the mediated model achieves a significant improvement in fit over the constrained model. If OLC causes a total mediating effect, the coefficient of the relationship between compassion and firm performance in the constrained model will not improve the fit; in the opposite case, the mediation would be partial (Beltrán-Martín et al., 2008). The fit indexes for the models are presented in Table 3. The $\chi^{2}$ test of differences between the mediated model and the constrained model showed a non-significant difference in the $\chi^{2}(\mathrm{p}>0.05)$. Thus, the relationship between compassion and firm performance in the mediated model doesn't significantly improves the fit of the constrained model, evidencing the total mediation effect of OLC in the model. Consequently, compassion affects firm performance indirectly (through OLC), thus supporting H2.

Insert Table 3 Here 
Insert Figure 1 Here

\section{Study 2: Sample and data collection}

The study 2 is focused on a population of 3 to 5 stars Hotels located in Spain. In a first step, we used SABI (Sistema de Análisis de Balances Ibérico) Spanish economic database as initial screening of the Hotel population. Hotels included in the sample fulfilled these characteristics: 3 stars (26\%); 4 stars (59\%); and 5 stars (15\%). We focused on these Hotels as their human capital is highly qualified and professional (Ordanini and Parasuraman, 2011). Data collection was carried out during 5 consecutive months (from January to May 2014). Managers of these hotels answer the questionnaires by telephone. Most of the managers who replied were reception managers (64\%), but we also obtained answers from administration managers (5\%), marketing managers $(14 \%)$, or even hotel managers $(17 \%)$. Finally, we obtained a sample of 160 hotels selected for our data analysis.

\section{Study 2: Descriptive statistics, psychometric properties of measurement scales and control variables}

Table 4 presents the descriptive statistics of the indicators considered in the study (i.e. means, standard deviations) and correlation factors. We can observe that all Cronbach's alpha coefficient values and those for composite reliability are above the minimum acceptable value 0.7 (Nunnally, 1978) and the average variance extracted shows values greater than the recommended minimum of 0.5 (Hair et al. 1998; Nunnally, 1978). Moreover, the correlations indicate that compassion and OLC interrelate positively and significantly. Again, the correlation between compassion and firm performance is not significant. Moreover, only one dimension of OLC (acceptance of risk) interrelates significatively with firm performance. Finally, the reliability information of each scale is presented in the Table 5, confirming the reliability of the scales employed. 
Insert Table 4 Here

Insert Table 5 Here

Moreover, results of the confirmatory factor analysis with the 22 indicators loading onto a single factor $(\chi 2(209)=1,945.754 ; \mathrm{CFI}=0.379 ; \mathrm{RMSEA}=0.246$; BBNNFI $=0.313)$ showed a poor fit. $\mathrm{In}$ accordance, this indicates the non-existence of problems associated to common method variance in this study.

Control variables. To take account of the external sources that can alter firm performance, we have included firm size and firm age as a control variable.

\section{Study 2: Results}

Results from SEM in the study 2 indicate an adequate fit of the model (Chi-Square $=380.352$; degrees of freedom $=244$; Bentler-Bonet Non-Normed Fit $=0.954$; Index Comparative Fit Index: 0.959; root mean square error of approximation $=0.047$ ) (see Table 7). Indeed, regression coefficients of the model indicate a positive relationship between compassion and OLC $(\beta 2=0.498 ; \mathrm{t}=3.473 ; \mathrm{p}<0.01)$ and between OLC and firm performance $(\beta 3=0.312 ; \mathrm{t}=2.470 ; \mathrm{p}<0.01)$, and a non-significant effect between compassion and firm performance $(\beta 1=-0.211 ; \mathrm{t}=-1.758 ; \mathrm{p}>0.05)$. Therefore, $\mathrm{H} 1$ is not confirmed again.

On the other hand, the results of decomposition effects indicate an indirect significant effect between compassion and firm performance with a value of $0.209(\mathrm{t}=2.527)$. This indicates a mediating effect through OLC. As we did in the study 1, we compared the mediated model to a constrained model to confirm whether this mediating effect is partial or total. As we can see in Table 6, the relationship between compassion and firm performance in the mediated model doesn't significantly improves the fit of the constrained model, evidencing the total mediation effect of OLC in the model. 
Consequently, this second study also confirms that compassion affects firm performance indirectly (through OLC), thus supporting $\mathrm{H} 2$ as well.

Insert Table 6 Here

Insert Table 7 Here

Moreover, we also performed the bootstrapping method by AMOS (MacKinnon et al., 2002; Preacher and Hayes, 2004) using Monte Carlo estimation method. This method enabled us to determine more accurately what the direct and indirect effect of a variable was when the samples were not big, as well as the confidence intervals of the indirect effects (Efron and Tibshirani, 1994; Shrout and Bolger, 2002). The null hypothesis, which proposed that $x$ had no indirect effect on $y$ via $m$, was ruled out when the confidence interval was above or below zero. The results from bootstrapping analyses showed that OLC fully mediated the relationship between compassion and firm performance, since the direct relationship between compassion and firm performance was non-significant ( $\beta=.02, \mathrm{n} . \mathrm{s})$. The estimated indirect effect compassion had on firm performance was 0.135 . The 95 percent bias corrected confidence intervals for the indirect effect were between 0.018 and 0.270 , and there was a pvalue of 0.025 for the two-tailed significance test. Hence, the standardized indirect effect compassion had on firm performance was significantly different to zero at a level of 0.025 and we can discard the null hypothesis of no mediation effect. Consequently, we may conclude that, as expected, OLC mediates the relationship between compassion and firm performance (see Figure 2).

Insert Figure 2 Here 


\section{DISCUSSION}

Over the last few years a growing number of studies has begun to explore the role of compassion in organizations. However, these studies have predominantly consisted in theoretical proposals highlighting the potential benefits of compassion at work. Accordingly, in order to advance in the study of compassion, this research has empirically examined some of the possible consequences of compassion. In this sense, our findings provide two main contributions to the management discipline. Firstly, this study advances in the empirical demonstration of the benefits of compassion in organizations. The results of this study demonstrate how compassion affect firm performance. Thus, these findings contribute to explain the performance implications of compassion, a large gap in the literature that has been set aside until now. Secondly, the study findings indicate that the performance advantages that accrue from compassion can be better understood by considering OLC as an explanatory and mediating mechanism. In other words, this study also provides empirical evidence about the role of compassion as an antecedent of a collective phenomenon such as organizational learning that can be considered a competitive advantage. In sum, the results confirm that workplace compassion improves organizational performance and learning capability.

\section{Theoretical and practical implications}

The study findings indicate that when compassion is propagated among organizational members, organizations are better able to learn thus obtaining a competitive advantage that is difficult to imitate and leads to higher firm performance. Results of the study are consistent with a new and alternative management paradigm, based on a humanistic model centred on other-interest, where care and compassion become central principles in the organizational life and functioning. To date, principles or values such as compassion, caregiving, altruism or empathic concern have been marginalized by the academic field of management (Rynes et al., 2012). However, this study demonstrates that the exhibition of qualities such as compassion, vulnerability or caring can be considered as sources of great strength that can be a source of competitive advantage contributing to improve levels of firm performance.

Organizations may be places of healing where every organizational member who experience suffering could feel the support of their organization. However, the proliferation of compassion in organizations requires a set of systemic organizational factors, such as values, practices or routines which help to collectively notice, feel and respond to suffering (Kanov et al., 2004). Compassion can be fuelled through physical architecture -by making members more accessible each other, so they can notice and respond more easily to others' suffering; by an organizational culture based on the values of concern and open expression of suffering; through communication systems that helps to alert the presence of pain in the organization; or modelling by leadership as leaders' expression of compassion and concern contribute to propagate these feelings and behaviors in the organization (Kanov et al., 2004). 
Moreover, HR practices may also contribute to the proliferation of compassion in organizations. In this sense, Chiva (2014) recently proposed a new HRM system -the common welfare HRM systemthat spreads compassion and altruism throughout the organization. HRM practices of this system are focused on concern for the welfare of others and the transcendence of ego by serving others. For example, recruitment and selection practices look for people motivated to act compassionately.

Although evidence has confirmed the positive consequences of workplace compassion, it has also the potential to negatively impact organizations if compassion is not supported by the organizational system. Individual expressions and acts of compassion in which organizational members engage may lead to experience emotional exhaustion and burnout, that in turn are costly for the organization (Kanov et al., 2004; Frost, 2003). Thus, organizational practices and processes should be aimed to replenish emotional resources expended by feeling and responding to pain. Leadership support for individuals who engage in compassion, collective responsibility in giving compassion, employee coordination in compassionate responses or psychological professional attention, may help to recover individual emotional exhaustion and burnout caused by engaging in acts of compassion.

Particularly, practicing a compassionate leadership -one who feels the pain of individuals, seeks selflessly the greatest good for others, moves by the followers hurt and pain and shows empathy- may inspire others to act compassionately. As leader serves as a model for subordinates, if leaders demonstrate their compassion towards others, they may spread acts of compassion throughout the members of the organization (Dutton et al., 2002). Moreover, when a leader leads with compassion, followers may be more predisposed to freely express themselves and find ways to move away from their suffering (Grant, 2008). In sum, a compassionate leadership may be a cornerstone to build organizations where people are moved by compassion and demonstrates care for others.

Organizations must pay attention to the conditions of the workplaces to create organizational environments where compassion and care become essential values and proliferate across organizational boundaries. As business has become more dehumanized and impersonal, organizational systems are failing to promote human flourishing and collective organizational processes (Worline and Dutton, 2017). This study indicates that organizations can benefit from moving away from values such self-interest, domination or aggressiveness at workplace to build work environments based on the pillars of compassion and caring.

\section{Study limitations and future lines of research}

As with all research, the limitations of this study should be acknowledged. First, respondents are managers, so individual employees' responses about the variables examined were not collected. However, managers can provide an accurate overview of the presence of some organizational 
processes and collective behaviors or about the overall levels of economic performance (RodriguezSanchez et al., 2019). In this research our aim was to examine the overall presence of organizational learning processes, existence of acts and feelings of compassion across the boundaries of the organization and results of organizational economic performance. Accordingly, we consider these overall variables can be measured through the responses of managers. In any case, future research may provide stronger support of these relationships by using also employees as respondents. Moreover, responses were obtained at a single time point. Thus, conclusions about the direction of cause and effects could not be inferred. Longitudinal studies are required in order to corroborate the causal effect of the relationships.

This study provides empirical support for a promising area of management research such is compassion in organizations. However, more empirical studies are needed to identify the relationships between compassion and other organizational variables. Examining the organizational conditions and practices (i.e., HR practices, types of organizational structures, physical architecture, leadership styles, organizational culture, values) that spread compassion in organizations may be a fruitful research area. For example, the physical architecture of a department may engender a considerable capacity for collective noticing, sensemaking, feeling, and responding (e.g., a department without architectural barriers that facilitates interaction between unit members). Another example of a practice in an organization to spread compassion can be regular team meetings in which members are encouraged to talk about how they are feeling about their work, and about non-work issues. This mechanism allows members to reveal and talk openly about their pain as well as share their emotional responses to colleagues' suffering (Kanov, et al., 2004). Likewise, organizational leadership can also contribute to the enabling of collective feeling around pain. When leaders are open to the expression of certain feelings and show concern for members' pain, organizational members will be much more likely to experience compassionate feelings as legitimate and to share them openly with their colleagues (Frost, 2003). Organizations may also have centrally coordinated mechanisms for the collection of resources towards distressed employees or the organization of collective gifts or memorials. For example, an organization can have a system that allows employees to donate their paid vacation and personal days to others who need time off because of painful or difficult circumstances (Dutton et al., 2002).

Finally, due to the evidence showing the benefits of compassion within organizations, the relationship between compassion and other significant organizational outcomes (i.e., innovation performance, quality service, organizational commitment, turnover intention, organizational trust) and behaviors (i.e., OCB, collaboration, engagement) should addressed by future research. This will allow ascertain the potential of compassion within organizations. 


\section{References}

Alegre, J. and Chiva, R. (2008), “Assessing the impact of organizational learning capability on product innovation performance: An empirical test”, Technovation, Vol. 28 No. 6, pp. 315-326.

Alegre, J. and Chiva, R. (2013), "Linking entrepreneurial orientation and firm performance: the role of organizational learning capability and innovation performance", Journal of Small Business Management, Vol. 51 No. 4, pp. 491-507.

Amabile, T., Conti, R., Coon, H., Lazenby, J. and Herron, M. (1996), “Assessing the work environment for creativity", Academy of Management Journal, Vol. 39 No. 5, pp. 1154-1184.

Atkins, P. W. and Parker, S. K. (2012), "Understanding individual compassion in organizations: The role of appraisals and psychological flexibility", Academy of Management Review, Vol. 37 No. 4, pp. 524-546.

Backhaus, K. and Tikoo, S. (2004), "Conceptualizing and researching employer branding. Career Development International", Vol. 9 No. 5, pp. 501-517.

Barney, J. (1995), "Looking inside for competitive advantage. The Academy of Management Executive", Vol. 9 No.4, pp. 49-61.

Batson, C. D. (1991), The altruism question: Toward a social-psychological answer, Hillsdale, NJ: Erlbaum.

Cameron, K., Mora, C., Leutscher, T. and Calarco, M. (2011), "Effects of positive practices on organizational effectiveness", The Journal of Applied Behavioral Science, Vol. 47 No. 3, pp. 266-308.

Cameron, K. S., Bright, D. and Caza, A. (2004), "Exploring the relationships between organizational virtuousness and performance", American Behavioral Scientist, Vol. 47 No.6, pp. 766-790.

Camps, J. and Luna-Arocas, R. (2009), "High involvement work practices and firm performance", The International Journal of Human Resource Management, Vol. 20, No. 5, pp. 1056-1077.

Camps, J. and Luna-Arocas, R. (2012), “A matter of learning: How human resources affect organizational performance", British Journal of Management, Vol. 23, No. 1, pp. 1-21. 
Camps, J., Oltra, V., Aldás-Manzano, J., Buenaventura-Vera, G. and Torres-Carballo, F. (2016), "Individual performance in turbulent environments: The role of organizational learning capability and employee flexibility", Human resource management, Vol. 55 No. 3, pp. 363-383.

Chiva, R. (2014), “The common welfare human resource management system: A new proposal based on high consciousness", Personnel Review, Vol. 43 No.6, pp. 937-956.

Chiva, R. and Alegre, J. (2005), "Organizational learning and organizational knowledge: towards the integration of two approaches", Management learning, Vol. 36 No.1, pp. 49-68.

Chiva, R. and Alegre, J. (2009), "Organizational learning capability and job satisfaction: An empirical assessment in the ceramic tile industry", British Journal of Management, Vol. 20 No. 3, pp. 323-340.

Chiva, R., Alegre, J. and Lapiedra, R. (2007), "Measuring organisational learning capability among the workforce", International Journal of Manpower, Vol. 28 No.3/4, pp. 224-242.

Clark, C. (1997), Misery and company: Sympathy in everyday life, Chicago: The University of Chicago Press.

Cronbach, L. J. (1951), “Coefficient alpha and the internal structure of tests”, Psychometrika, Vol. 16 No. 3, pp. 297-334.

Dalai Lama (1995), The power of compassion, London: Thorsons.

DiBella, A. J., Nevis, E. C. and Gould, J. M. (1996), "Understanding organizational learning capability", Journal of management studies, Vol. 33 No. 3, pp. 361-379.

Dutton, J. E., Frost, P. J., Worline, M. C., Lilius, J. M. and Kanov, J. M. (2002), "Leading in times of trauma", Harvard Business Review, Vol. 80 No.1, pp. 54-61.

Dutton, J. E., Workman, K. M. and Hardin, A. E. (2014), “Compassion at work”, Annual Review of organizational Psychology and Organizational Behavior, Vol. 1 No.1, pp. 277-304.

Dutton, J. E., Worline, M. C., Frost, P. J. and Lilius, J. M. (2006), "Explaining compassion organizing", Administrative Science Quarterly, Vol. 51, pp. 59-96.

Dutton, J., Lilius, J. M. and Kanov, J. (2007), “The transformative potential of compassion at work", 
Handbook of transformative cooperation: New designs and dynamics, pp. 107-124.

Edmondson, A. C. (2012), Teaming: How organizations learn, innovate, and compete in the knowledge economy, San Francisco, CA: Jossey-Bass.

Efron, B. and Tibshirani, R. J. (1994), An introduction to the bootstrap, CRC press.

Elkjaer, B. (2003), “Organizational learning with a pragmatic slant”, International Journal of Lifelong Education, Vol. 22 No.5, pp. 481-494.

Feldman, M. S. and March, J. G. (1981), "Information in organizations as signal and symbol”, Administrative science quarterly, pp. 171-186.

Fornell, C. and Larcker, D. F. (1981), "Structural equation models with unobservable variables and measurement error: Algebra and statistics", Journal of marketing research, pp. 382-388.

Frost, P. J. (1999), “Why compassion counts!”, Journal of Management Inquiry, Vol. 8 No. 2, pp. 127-133.

Frost P.J., Dutton J.E., Worline M.C., et al. (2000), "Narratives of compassion in organizations", in Fineman, S. (Ed.), Emotion in Organizations, Thousand Oaks, CA: SAGE, pp. 25-45.

Frost, P. J. (2003), Toxic emotions at work: How compassionate managers handle pain and conflict, Boston, MA: Harvard Business School Press.

Frost, P. J., Dutton, J. E., Maitlis, S., Lilius, J. M., Kanov, J. M. and Worline, M. C. (2006), “Seeing organizations differently: Three lenses on compassion", The Sage handbook of organization studies, Vol. 2, pp. 843-866.

George, J. M. (2014), “Compassion and capitalism: Implications for organizational studies”, Journal of Management, Vol. 40 No. 1, pp. 5-15.

Goh, S. and Richards, G. (1997), "Benchmarking the learning capability of organizations", European Management Journal, Vol. 15 No. 5, pp. 575-583.

Grant, A., Dutton, J.E. and Rosso, B. (2008), “Giving commitment: Employee support programs and the prosocial sensemaking process", Academy of Management Journal, Vol. 51 No. 5, pp. 898-918. 
Grant, K. (2008), "Who are the lepers in our organizations? A case for compassionate leadership", Business Renaissance Quarterly, Vol. 3 No.2, pp. 75-91.

Guinot, J., Chiva, R. and Mallén, F. (2013), “Organizational trust and performance: Is organizational learning capability a missing link?", Journal of Management \& Organization, Vol. 19 No. 5, pp. 559582.

Gupta, M., Kumar, V. and Singh, M. (2014), "Creating satisfied employees through workplace spirituality: A study of the private insurance sector in Punjab (India)", Journal of business ethics, Vol. 122 No.1, pp. 79-88.

Haidt, J. (2003), "Elevation and the positive psychology of morality", in C. Keyes \& J. Haidt (Eds.), Flourishing: The positive person and the good life, Washington, DC: American Psychological Association, pp. 275-289.

Hair, H. F., Anderson, R. E., Tatham, R. L. and Black, W. C. (1998), Multivariate data analysis, London: Prentice Hall.

Jiménez-Jiménez, D. and Sanz-Valle, R. (2011), "Innovation, organizational learning, and performance", Journal of business research, Vol. 64 No. 4, pp. 408-417.

Kanov, J. M., Maitlis, S., Worline, M. C., Dutton, J. E., Frost, P. J. and Lilius, J. M. (2004), "Compassion in organizational life", American Behavioral Scientist, 47(6), pp. 808-827.

Lilius, J. M., Kanov, J. M., Dutton, J. E., Worline, M. C. and Maitlis, S. (2012), “Compassion revealed: What we know about compassion at work (and where we need to know more)", in K. S. Cameron and G. M. Spreitzer (Eds.), Oxford handbook of positive organization scholarship, New York: Oxford University Press, pp. 273-287.

Lilius, J. M., Worline, M. C., Dutton, J. E., Kanov, J. M. and Maitlis, S. (2011), “Understanding compassion capability”, Human relations, Vol. 64 No.7, pp. 873-899.

Lilius, J. M., Worline, M. C., Maitlis, S., Kanov, J., Dutton, J. E. and Frost, P. (2008) “The contours and consequences of compassion at work", Journal of Organizational Behavior: The International Journal of Industrial, Occupational and Organizational Psychology and Behavior, Vol. 29 No. 2, pp. 193-218. 
Lin, H. F. (2007), "Knowledge sharing and firm innovation capability: An empirical study", International Journal of Manpower, Vol. 28, pp. 315-332.

MacKinnon, D. P., Lockwood, C. M., Hoffman, J. M., West, S. G. and Sheets, V. (2002), “A comparison of methods to test mediation and other intervening variable effects", Psychological methods, Vol. 7 No.1, pp. 83.

Madden, L. T., Duchon D., Madden, T. M. and Plowman, D. A. (2012), "Emergent organizational capacity for compassion", Academy of Management Review, Vol. 37 No.4, pp. 689-708.

Marshall, J., Smith, S. and Buxton, S. (2009), "Learning organisations and organisational learning: What have we learned?", Management Services, Vol. 53 No.2, pp. 36.

Melé, D. (2012). The firm as a "community of persons": A pillar of humanistic business ethos. Journal of Business Ethics, Vol. 106 No.1, pp. 89-101.

Morabito, V., Themistocleous, M. and Serrano, A. (2010), “A survey on integrated IS and competitive advantage", Journal of Enterprise Information Management, Vol. 23 No. 2, pp. 201-214.

Nunnally, J. (1978), Psychometric theory, New York: McGraw-Hill.

Ordanini, A. and Parasuraman, A. (2011), "Service innovation viewed through a service-dominant logic lens: a conceptual framework and empirical analysis", Journal of Service Research, Vol. 14 No. 1, pp. 3-23.

Petchsawang, P. and Duchon, D. (2009), "Measuring workplace spirituality in an Asian context", Human resource development international, Vol. 12 No. 4, pp. 459-468.

Petchsawang, P. and Duchon, D. (2012), "Workplace spirituality, meditation, and work performance", Journal of management, spirituality \& religion, Vol. 9 No. 2, pp.189-208.

Petchsawang, P. and McLean, G. N. (2017), "Workplace spirituality, mindfulness meditation, and work engagement”, Journal of Management, Spirituality \& Religion, Vol. 14 No. 3, pp. 216-244.

Podsakoff, P. M. and Organ, D. W. (1986), "Self-reports in organizational research: Problems and prospects", Journal of Management, Vol. 12 No. 4, pp. 531-544. 
Podsakoff, P. M., MacKenzie, S. B., Lee, J. Y. and Podsakoff, N. P. (2003), “Common method biases in behavioral research: A critical review of the literature and recommended remedies", Journal of Applied Psychology, Vol. 88 No. 5, pp. 879-903.

Powley, E.H. (2009), "Reclaiming resilience and safety: Resilience activation in the critical period of crisis", Human Relations, Vol. 62 No.9, pp. 1289-1326.

Preacher, K. J. and Hayes, A. F. (2004), SPSS and SAS procedures for estimating indirect effects in simple mediation models, Behavior research methods, instruments, \& computers, Vol. 36 No.4, pp. 717-731.

Rodríguez-Sánchez, A., Guinot, J., Chiva, R. and López-Cabrales, Á. (2019), "How to emerge stronger: Antecedents and consequences of organizational resilience", Journal of Management \& Organization, pp. 1-18.

Rynes, S. L., Bartunek, J. M., Dutton, J. E. and Margolis, J. D. (2012), Care and compassion through an organizational lens: Opening up new possibilities.

Shrout, P. E. and Bolger, N. (2002), "Mediation in experimental and nonexperimental studies: new procedures and recommendations", Psychological methods, Vol. 7 No.4, pp. 422.

Simosko, N. (2015), "Leading innovation in the workplace. First step: Cultivate compassion”, NTT innovation institute, Inc. (blog), October 6, 2015, from http://www.ntti3.com/blog/leading-innovationin-the-workplace-first-stepcultivate-compassion/.

Stamm, B.H. (2002), "Measuring compassion satisfaction as well as fatigue: Developmental history of the compassion satisfaction and fatigue test", In Figley C (ed.) Treating Compassion Fatigue, New York, NY: Routledge, pp. 107-122.

Tippins, M. J. and Sohi, R. S. (2003), "IT competency and firm performance: is organizational learning a missing link?", Strategic management journal, Vol. 24 No.8, pp. 745-761.

Worline, M. and Dutton, J. E. (2017), Awakening compassion at work: The quiet power that elevates people and organizations, Berrett-Koehler Publishers.

Zaslow, J. (2002), "New index aims to calculate the annual cost of despair", The Wall Street Journal, 
Vol. 20, pp. 1-12. 


\section{TABLES}

Table I. Study 1: Means, standard deviation and correlation factors $(\mathrm{N}=\mathbf{2 4 3}){ }^{(1)}$

\begin{tabular}{|c|c|c|c|c|c|c|c|c|c|}
\hline & Mean & S.D. & FPER & EXP & RISK & INT & DIA & TDEC & COMP \\
\hline $\begin{array}{l}\text { Firm } \\
\text { performance } \\
(\text { FPERF) }\end{array}$ & 5.27 & 0.980 & 1 & & & & & & \\
\hline $\begin{array}{l}\text { Experimenta } \\
\text { tion }(\mathrm{EXP})\end{array}$ & 5.60 & 0.942 & $0.188^{*}$ & 1 & & & & & \\
\hline $\begin{array}{l}\text { Acceptance } \\
\text { of risk } \\
\text { (RISK) }\end{array}$ & 4.77 & 1.358 & 0.019 & $0.354 *$ & 1 & & & & \\
\hline $\begin{array}{l}\text { Interaction } \\
\text { with } \\
\text { environment } \\
\text { (INT) }\end{array}$ & 4.86 & 1.301 & 0.114 & $0.263 *$ & $0.295 *$ & 1 & & & \\
\hline $\begin{array}{l}\text { Dialog } \\
\text { (DIA) }\end{array}$ & 5.76 & 0.997 & $0.201 *$ & 0.672 & $0.238 *$ & $0.363^{*}$ & 1 & & \\
\hline $\begin{array}{l}\text { Taking } \\
\text { decisions } \\
\text { (TDEC) }\end{array}$ & 4.96 & 1.176 & 0.108 & $0.479 *$ & $0.315^{*}$ & $0.305^{*}$ & $0.591 *$ & 1 & \\
\hline $\begin{array}{l}\text { Compassion } \\
\text { (COMP) }\end{array}$ & 5.52 & 0.944 & 0.108 & $0.539 *$ & $0.232 *$ & $0.219 *$ & $0.554 *$ & $0.388^{*}$ & 1 \\
\hline
\end{tabular}

*Significant correlation $(\mathrm{p}<0.01)$

(1) For the standard deviations and correlations between factors, we have worked with the mean for the items making up each dimension. 
Table 2. Study 1: Reliability of the measurement scales.

\begin{tabular}{lccc}
\hline Construct & Cronbach's $\alpha$ & $\begin{array}{c}\text { Composite } \\
\text { reliability }\end{array}$ & $\begin{array}{c}\text { Extracted mean } \\
\text { variance }\end{array}$ \\
\hline Compassion & 0.930 & 0.932 & 0.777 \\
Firm performance & 0.846 & 0.881 & 0.713 \\
Experimentation & 0.886 & 0.888 & 0.799 \\
Acceptance of risk & 0.771 & 0.811 & 0.691 \\
Interaction with the & 0.834 & & 0.637 \\
environment & & 0.839 & 0.745 \\
Dialog & 0.918 & 0.921 & 0.842 \\
Participative & 0.941 & 0.941 & \\
decision-making & & & \\
\hline
\end{tabular}

Table 3. Study 1: Fit indices of the Structural Equation Models.

\begin{tabular}{lcccccc}
\hline Model & Chi-square & df & p & BBNNFI & CFI & RMSEA \\
\hline $\begin{array}{l}\text { Mediated } \\
\text { model }\end{array}$ & 341.624 & 244 & 0.000 & 0.987 & 0.989 & 0.025 \\
$\begin{array}{l}\text { Constrained } \\
\text { model }\end{array}$ & 342.360 & 245 & 0.000 & 0.988 & 0.989 & 0.025 \\
& & & & & &
\end{tabular}


Table 4. Study 2: Means, standard deviation and correlation factors $(\mathrm{N}=160){ }^{(1)}$

\begin{tabular}{|c|c|c|c|c|c|c|c|c|c|}
\hline & Mean & S.D. & COMP & FPER & EXP & RISK & INT & DIA & TDEC \\
\hline $\begin{array}{l}\text { Compassion } \\
\text { (COMP) }\end{array}$ & 5.901 & 0.833 & 1 & & & & & & \\
\hline $\begin{array}{c}\text { Firm } \\
\text { performance } \\
(\text { FPERF })\end{array}$ & 4.402 & 1.042 & -0.049 & 1 & & & & & \\
\hline $\begin{array}{c}\text { Experimenta } \\
\text { tion }(\mathrm{EXP})\end{array}$ & 5.334 & 1.135 & $0.328 *$ & 0.048 & 1 & & & & \\
\hline $\begin{array}{c}\text { Acceptance } \\
\text { of risk } \\
\text { (RISK) }\end{array}$ & 4.181 & 1.447 & $0.323^{*}$ & $0.234 *$ & $0.525^{*}$ & 1 & & & \\
\hline $\begin{array}{l}\text { Interaction } \\
\text { with } \\
\text { environment } \\
\text { (INT) }\end{array}$ & 4.714 & 1.330 & $0.352 *$ & 0.118 & $0.257 *$ & $\begin{array}{c}0.538 \\
*\end{array}$ & 1 & & \\
\hline $\begin{array}{l}\text { Dialog } \\
\text { (DIA) }\end{array}$ & 5.591 & 1.004 & $0.414^{*}$ & 0.116 & $0.420 *$ & $\begin{array}{c}0.453 \\
*\end{array}$ & $\begin{array}{l}0.439 \\
*\end{array}$ & 1 & \\
\hline $\begin{array}{c}\text { Taking } \\
\text { decisions } \\
\text { (TDEC) }\end{array}$ & 4.050 & 1.628 & $0.333 *$ & 0.124 & $0.552 *$ & $\begin{array}{c}0.552 \\
*\end{array}$ & $\begin{array}{c}0.439 \\
*\end{array}$ & $\begin{array}{c}0.535 \\
*\end{array}$ & 1 \\
\hline
\end{tabular}

*Significant correlation $(\mathrm{p}<0.01)$

(1) For the standard deviations and correlations between factors, we have worked with the mean for the items making up each dimension. 
Table 5. Study 2: Reliability of the measurement scales.

\begin{tabular}{lccc}
\hline Construct & Cronbach's $\alpha$ & Composite reliability & $\begin{array}{c}\text { Extracted mean } \\
\text { variance }\end{array}$ \\
\hline Compassion & 0.895 & 0.900 & 0.694 \\
Firm performance & 0.947 & 0.955 & 0.843 \\
Experimentation & 0.904 & 0.907 & 0.831 \\
Acceptance of risk & 0.829 & 0.832 & 0.714 \\
& & & 0.737 \\
Interaction with the & 0.889 & 0.893 & 0.669 \\
environment & & & 0.857 \\
Dialog & 0.886 & 0.889 & \\
Participative decision-making & 0.945 & 0.947 & \\
\hline
\end{tabular}

Table 6. Study 2: Fit indices of the Structural Equation Models

\begin{tabular}{lllllll}
\hline Model & Chi-square & df & $\mathrm{p}$ & BBNNFI & CFI & RMSEA \\
\hline Mediated model & 380.352 & 244 & .00 & .954 & .959 & .047 \\
$\begin{array}{l}\text { Constrained } \\
\text { model }\end{array}$ & 384.403 & 245 & .00 & .953 & .958 & .048 \\
\hline
\end{tabular}


Table 7. Table 7. Comparative analysis based on acceptable standards

\begin{tabular}{|c|c|c|c|}
\hline & $\begin{array}{c}\text { Acceptable } \\
\text { standard outcome }\end{array}$ & Study 1 & Study 2 \\
\hline \multicolumn{4}{|l|}{ Goodness of fit } \\
\hline $\begin{array}{l}\text { Normalized } \\
\text { Chi-square }\end{array}$ & $1-2$ & 1.40 & 1.56 \\
\hline$B B N N F I$ & $>0.90$ & 0.987 & 0.954 \\
\hline CFI & $\geq 0.90$ & 0.989 & 0.959 \\
\hline RMSEA & $<0.08$ & 0.025 & 0.047 \\
\hline \multicolumn{4}{|l|}{ Hypothesis } \\
\hline $\begin{array}{l}\text { Compassion and } \\
\text { firm perf }(\mathrm{Hl})\end{array}$ & \multirow{3}{*}{$\mathrm{t}$ value $>1.96$} & $\mathrm{t}=-0.761$ & $\mathrm{t}=-1.758$ \\
\hline $\begin{array}{l}\text { Compassion and } \\
\text { OLC }(\mathrm{H} 2)\end{array}$ & & $\mathrm{t}=8.418$ & $\mathrm{t}=3.473$ \\
\hline $\begin{array}{l}\text { OLC and firm } \\
\text { perf }(H 3)\end{array}$ & & $t=2.263$ & $\mathrm{t}=2.470$ \\
\hline
\end{tabular}

\section{FIGURES}

Figure 1. Study 1: Results of the research model.

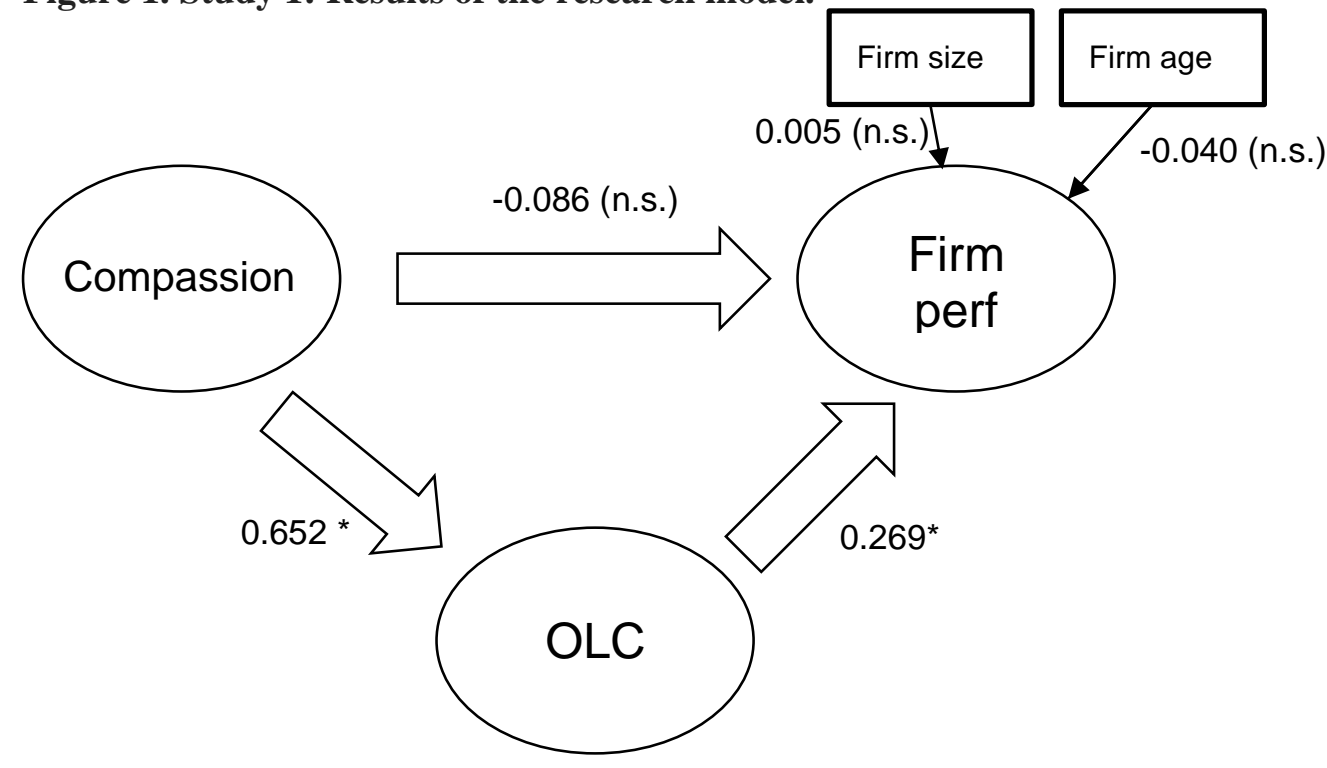

Notes:

(*) Significant relationship $(\mathrm{p}<0.5)$

(n.s.) no significant relationship 
Figure 2. Study 2: Results of the research model.

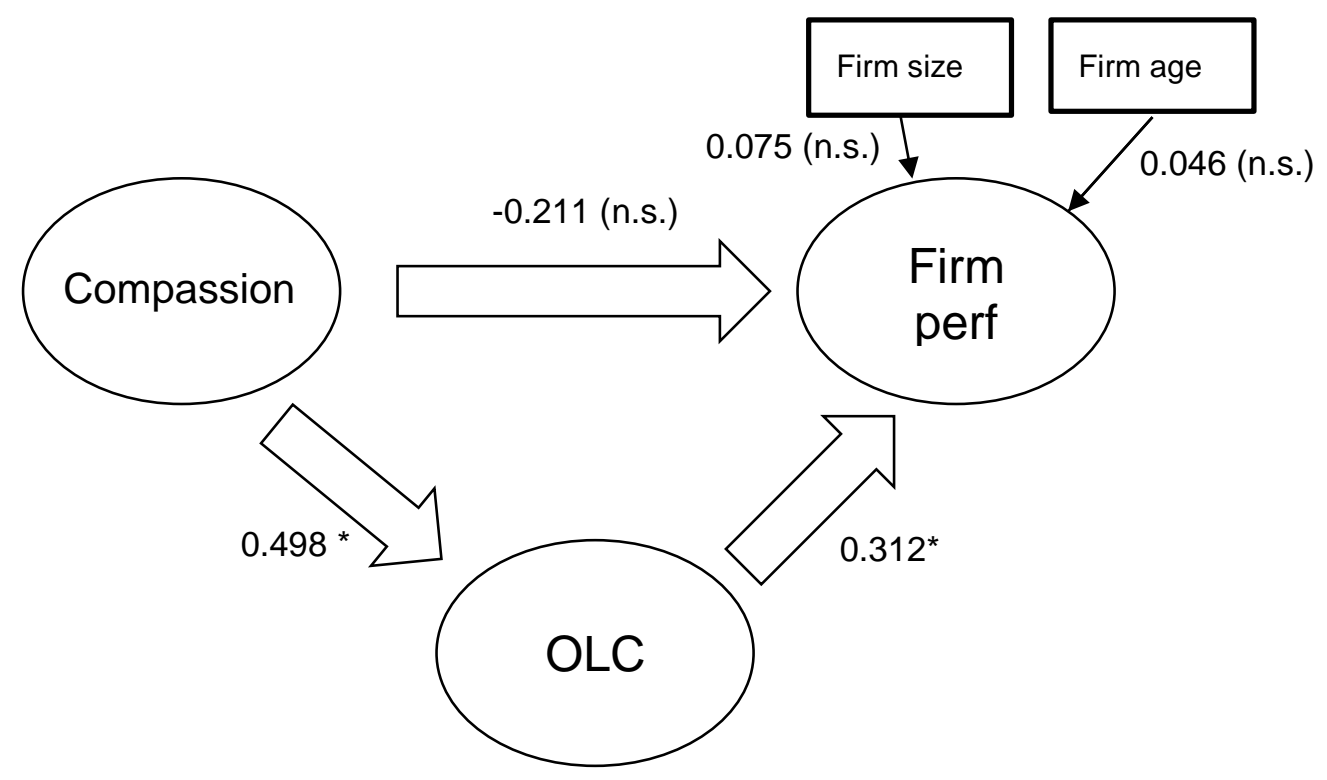

Notes:

(*) Significant relationship $(\mathrm{p}<0.5)$

(n.s.) no significant relationship 